\title{
CONTESTING “IRAQ”: A SOCIAL CONSTRUCTIVIST EXPLANATION
}

\author{
Lawrence Craig Bailie ${ }^{1}$ \\ School for Security and Africa Studies, Faculty of Military \\ Science, Stellenbosch University
}

\begin{abstract}
Iraq, following the 2003 US invasion, was more than just a site of physical conflict; it was also an event on the ground that encompassed a contest around classification. The reason for this contest - one that goes beyond the political considerations during that time - is the migration of the term "civil war". Using social constructivism as a theoretical lens of inquiry, sense is made of this migration. The empirical evidence that accompanies this theoretical work is drawn from the debate over the conflict in Iraq. This debate is used as a means by which to bring the contestation over the notion of "civil war" to the fore and reveal the migration of the term.
\end{abstract}

\section{Introduction}

Civil wars are believed to have experienced a steady increase in their "number, duration and sheer destructiveness" since the beginning of the $19^{\text {th }}$ century. ${ }^{2}$ Of the 124 cases of "civil war" that have been identified between the years 1816 and 1988, almost half occurred between 1945 and 1998. ${ }^{3}$ Duyvesteyn writes, "civil war has been the dominant form of war at least since the end of the Second World War". ${ }^{4}$ Another count indicates that more than a hundred civil wars have taken place since the end of the Cold War in 1989. Furthermore, there is an abundance of writing touching on or devoted entirely to the idea that "civil war" is changing. The significance of this idea has led to a distinction being made between "new" and "old” "civil wars". However, writing in 2001 and 2003 respectively Kalyvas and Berdal dispute the validity of a distinction between "old" and "new",

Scientia Militaria, South African Journal of Military Studies, Vol 39, Nr 2, 2011, pp. 117-140 doi: $10.5787 / 39-2-113$ while in the midst of the debate that followed the 2003 US invasion of Iraq, Keegan argued for the existence of only five "clear-cut" cases of "civil war" in history. ${ }^{6}$ These contradictory claims formed the backdrop to the study on why it is that Iraq, following the 2003 US 
invasion, was more than just a site of physical conflict, but also an event on the ground that encompassed a contest around classification. The answer to this question informs an understanding of the definition and classification of "civil war" in contemporary International Relations (IR) studies.

The increasingly prevalent claim regarding "civil wars" - that they have increased in their number and changed in their nature - is one that requires careful consideration. To say that a phenomenon has increased in occurrence while at the same time changing in nature seems problematic. How can it be known that "civil war" is increasing in occurrence if the nature by which it is understood is believed to have changed and continues to change? Put differently, how do we measure what we consider to be "civil war" as having increased if what we classify it by is believed to have been changing? The answer, to be revealed in the work that follows, is that the same term has come to be used to classify intra-state conflicts that are understood to be different from each other by their natures. Thus, the perception has been created that "civil wars" have been on the increase while also changing their nature, when in fact, it is the conceptual understanding of "civil war" that has changed. This claim that the notion of "civil war" is a contested and shifting one - is foundational to the purpose of this work noted in the opening passage.

The philosophy of language is an incredibly powerful tool to understand the world in which we live. It is one that has, however, been neglected in IR. As a result, little attention has been given to how the core concepts of IR are constructed and reconstructed (with the latter process encompassing what one might call the "migration of terms"). The contradictory claims noted above, suggest that "civil war" is a migratory term. It is the debate over the conflict in Iraq that offers empirical evidence for this and it is in light of social constructivist theory that we gain understanding as to how and why "civil war" can be a migratory term. It is because it is in fact a migratory term that there was not only conflict in Iraq, but also a contest over how that conflict was to be classified. In order to understand and recognise the conceptual migration evidenced in the Iraq debate, its process must first be described in words. In doing so, it is to the theory of social constructivism that we now turn.

\section{Two worlds constituted by different objects}

Social constructivism (constructivism in short) came slowly to the study of IR but it has helped to situate issues of language alongside those of understanding and policy. In its essence, constructivism holds that "we occupy a world of our 
making". ${ }^{7}$ Proponents of this approach claim, "the objects of our knowledge are not independent of our interpretations and our language". ${ }^{8}$ In making reference to "objects of our knowledge", constructivists mean that there are also objects not of our knowledge. To say that an object is of our knowledge is to say that it comes from our knowledge, is a product of our knowledge, exists because of our knowledge, and is created by our knowledge. To say that an object is not of our knowledge would mean that it does not come from our knowledge, but exists irrespective thereof. This distinction is important because it brings understanding to the constructivist code that "we occupy a world of our making" and more particularly, it brings understanding to what that "world" is and how it is made. ${ }^{9}$ Put in the form of a question: what are these so-called "objects" and what, besides the fact that one kind exists irrespective of our knowledge and the other because of our knowledge, distinguishes them? As this explanation suggests,

[S]ocial facts, which are facts only by human agreement and which account for the majority of the facts in IR, differ from rocks and flowers, because, unlike the latter, their existence depends on human consciousness and language. In other words, social facts depend, by way of collective understanding and discourse, on the attachment of collective knowledge to physical reality. ${ }^{10}$

Similarly,

Most objects of international relations, unlike trees, rocks, or glaciers, exist only by virtue of human acts of creation which happen in a cultural, historical, and political context of meaning. They are social facts, rather than purely material ones, that exist because of the meaning and value attributed to them. ${ }^{11}$

For constructivists, those objects not of our knowledge are therefore the physical phenomena that make up the natural world. So, as noted, rocks, flowers, trees and glaciers all exist prior to and apart from our knowledge. The objects of our knowledge are the social phenomena (referred to above as "social facts") that make up the social world. These social phenomena come into being when we attach knowledge to physical reality. Men and women for example,

... make ... states which are historical constructs. States are artificial creations and the state system is artificial too; it is made by men and women and if they want to, they can change it and develop it in new ways. $^{12}$ 
Therefore, the difference between objects not of our knowledge and objects of our knowledge is that the former constitutes a concrete physical reality that can be touched and seen, while the latter is an abstract notion denoting a physical reality that cannot be touched because it is not concrete, yet can be seen because it exists in relationship between concrete entities. This is why constructivists contend that, "the social world is in part constructed of physical entities. But it is the ideas and beliefs concerning those entities which are most important: what those entities signify in the minds of people."13 It is the ideas and beliefs concerning physical entities and the communication of these ideas and beliefs through language that is most important in the construction of the social world. Normative or ideational structures are therefore more important than material structures in shaping the behaviour of social and political actors.

\section{The constitutive role of language vis-à-vis the social world}

The "attaching of knowledge" to physical reality involves interpreting the physical reality (i.e. making it understandable) through the use of words (i.e. language). This is where the constitutive role of language comes into play and it is why constructivists argue, "the objects of our knowledge [i.e. social phenomena] are not independent of our interpretations and our language". ${ }^{14}$ The philosopher Ludwig Wittgenstein argues, "language itself is constitutive of reality". ${ }^{15}$ In a similar vein, constructivists believe that "[l]anguage is bound up in the world rather than a mirror of it" 16 "Without language we could not begin to communicate with one another, attribute meaning to objects or acts in the world, think individual thoughts, or express feelings." ${ }^{17}$ It is through communication that normative and ideational structures work their influence. ${ }^{18}$ Until something can be described or interpreted with words, that thing will not be understood or even exist in the social world. Consequently, it is the words ascribed to something that will give it existence and determine how it is understood and what influence it will have. Examples of the social phenomena that result from this construction process would include all those things that Fierke attributes as "objects of international relations" - one of which would be the notion of "civil war". These social phenomena make up the social world or the world of human interaction, which would include the political world, as it is made up of interactions between human beings or structures constituted and driven by human beings. This is why Jackson and Sørensen write that human relations include international relations, and why what Fierke refers to as the "objects of international relations" are also objects of the social world. ${ }^{19}$ The social world, of which "civil war" is a constituent, is therefore not something like rocks, flowers, trees or glaciers: 
It does not exist on its own. It exists only as an intersubjective awareness among people; in that sense the ... [social world] is constituted by ideas, not by material ... [objects or phenomena]. It is a human invention or creation not of a physical or material kind but of a purely intellectual and ideational kind. It is a set of ideas, a body of thought, a system of norms, which has been arranged by certain people at a particular time and place. ${ }^{20}$

\section{Time and the challenge to realism}

To make a claim that "civil war" has "changed” can therefore mean only one thing - the conceptual understanding of what "civil war" is has changed over time. Such a change is made possible by the fact that the construction of the social world is subject to interpretations and language, both of which change with time. Hermeneutics (the science of interpretation) contends, "that the process of finding meaning is inherently an interpretivist process of constructing a reality that is conditioned by time." 21 Scholars of hermeneutics argue then that the manner in which we construct the social world is conditioned by time. The meaning of "conditioning" is "circumstances... affecting the functioning or existence...of something". ${ }^{22}$ Consequently, it is not time in and of itself that conditions the construction of the social world, but rather the physical reality of events and circumstances that arise with the passing of time. As much as physical reality is the basis upon which humans construct the social world through interpretation and language, so too is this physical reality the basis upon which the social world is subject to change. Change occurs in the social world as interpretation and language are applied to the physical reality. As time passes, relationships change, effectively forming new kinds of relationships. In this process, the terms we use to identify concepts or social phenomena that are the products of how we interpret previous relations, may be used to identify the new relations. Miller tells us for example, "As worldview changes, so do the words that mark it. Sometimes the words stay the same, but their meanings are changed.”23 Thus constructivists believe, "The subjects of international politics ... are not static but ever evolving as they interact with each other and their environment" - that is, "In a situation of change, categories of identity or action are not likely to be static.,24

Tim Shaw refers to "the continuing 'crisis' in international relations at the end of the twentieth century: a somewhat disorganised world, in both intellectual 
and existential terms, of proliferating state and non-state actors, issues and institutions". ${ }^{25}$ This crisis in IR is a direct result of the passing of time and the inevitable change that comes with it. This change can either come to infringe upon or discard entirely the functionality of the concepts we conceive and use to describe (and to understand) the world in which we live. In the early 1970s, for example, "the possibility that IR theorizing would ... be reflective of the world it proclaimed to be capable of examining” was challenged. ${ }^{26}$ For Van der Westhuizen, one of the most profound challenges against this function, and more particularly, "Realism's statecentric affliction", came when the concepts of "transnationalism" and "interdependence" were introduced in coming to terms with new events or relations on the ground. ${ }^{27}$ In their formulation, they would have challenged and encouraged a rethinking of both the long-standing and more contemporary notions of "sovereignty”, "government”, "security”, and “democracy”. These are all examples of social phenomena whose conceptualisations have the potential to change, leading to a migration of the terms that identify them. The topic of the study on which this article reports, “civil war”, must be viewed in a similar light.

In as far as IR has been in crisis because of the challenges it faces in describing the world today, so too has the theory that has dominated IR since the end of the Second World War. World War Two formed the watershed between IR that concerned itself with how things ought to be and IR that concerns itself with how things really are. ${ }^{28}$ The latter mode of thinking is what gave rise to Realist theory, which viewed sovereign states as the primary units of analysis in an international system characterised by struggle and anarchy. ${ }^{29}$ The ability of the once dominant IR theory of realism to understand, define, explain and predict the political movements of the world in which we live has, however, come under siege. This has happened because the core concepts with which it made these understandings, definitions, explanations and predictions fall short of bringing understanding to contemporary events on the ground. It is no longer the case that the political events happening within states, between states, and across states necessarily fit the conceptual moulds set out by realism. This is why criticism has been levelled at Realist theory for naturalising or reifying "the international system by treating structures [embodied in terms and] which have a specific and transitory history as if they were 'permanent', 'normal' or 'given' political fixtures”. ${ }^{30}$ Where the need has existed, new terms have come into being in order to make sense of and to classify an unknown or not yet seen social (or political) world. Alternatively, longstanding terms have come to adopt new meanings. With regard to the latter, the realist understanding of "civil war" - challenged by the classification of the conflict in Iraq - is a case in point. Writing in 1997, Van der Westhuizen observed that, 
As states continue to concede much of their primacy to other nonstate actors, transnational flows and new global processes, mainstream IR theorising finds itself increasingly in disarray, unable to account for the multitude of forces sweeping through and simply past state borders. ${ }^{31}$

Similarly, Berdal explains how an important aspect of the fragmentation and multi-factionalism that is seen as an element unique to contemporary "civil wars" "lies in the transnational or transborder characteristics that many modern war economies have acquired”. "This is one reason why the terms 'intrastate', 'civil' or 'internal' used to describe conflicts are often so problematic.”33

IR theorists take cognisance of the array of non-state actors and institutions that have come to infringe on the role of the state as well as the political processes within it. In doing so, IR theorists underscore the challenge faced by mainstream IR theory in explaining political processes through the use of conventional concepts and units of analysis. One such theorist is Jessica Mathews, who in her paper entitled "Power Shift", makes the central argument that the power of the state is in decline. One reason for this decline is the "redistribution of power among states, markets, and civil society" that followed the end of the Cold War. ${ }^{34}$ Mathews explains how non-governmental and international organisations, multi-national corporations, open-market economies, global crime and improved technology, have all in some manner or form, deprived states of the power they once held while influencing the activities within state borders. She states, "it requires a mental leap to think of world politics in any terms other than occasionally cooperating but generally competing states, each defined by its territory and representing all the people therein". 35

This being said, a brief look at Rosenau's notion of "turbulence" - described as "an imaginative leap into world politics" - should prove appropriate. ${ }^{36}$ "Turbulence" may be described as that which "denotes the tensions and changes that ensue when the structures and processes that normally sustain world politics are unsettled and appear to be undergoing arrangement. ${ }^{, 37}$ One characteristic of this notion is a high degree of complexity - that is, the extensive interdependence of an excessive number of actors. ${ }^{38}$ The concept of "civil war" may therefore be described as undergoing turbulence in view of the quantity and interdependence of non-state entities that have come to infringe on activities within the state. In a similar fashion 
to Mathews, but with a more forthright challenge to mainstream IR theory, Rosenau highlights "exploding technologies and expanding interdependencies" as influencing activities within states. ${ }^{39}$ He goes so far as to say that the changes brought about by these factors justify theorising to begin anew, and that "post-international politics" should serve as an appropriate substitute for "international relations" when describing the interactions of world politics, when he states, "The very notion of 'international relations' seems obsolete in the face of an apparent trend in which more and more of the interactions that sustain world politics unfold without the direct involvement of nations or states. ${ }^{40}$

It is with an understanding of the increasing influence of non-state interactions upon events within the state that the Centre for the Study of Civil War established a work group to evaluate "the impact of external pressure or interference on the character and trajectory of civil wars". ${ }^{41}$ The leader of this workgroup, Pavel Baev, takes note not only of the forces that infringe upon the primary unit of analysis in realist theory, but also of the relationship between these forces and the contestation around the traditional notion of "civil war":

Civil war is an evolving phenomenon that does not lend itself easily to a clear definition since its "traditional" intra-state features are densely interwoven with increasingly complex international dimensions. The variety of external impacts and influences presents theoretical puzzles as well as political challenges; it also involves fundamental questions about the changing nature of states as key actors in the international system, since state borders are normally perceived as embracing the populations and societies within which civil wars play out, and they are the boundaries which are violated by all external interventions, whether sanctioned or forceful. ${ }^{42}$

The greater the impact of forces external to the state, on the internal workings of a state during a time of conflict, the more likely it is for the conflict in question to be different from the conventional realist conceptualisation of "civil war". Those academics, laymen and politicians who have come to understand and name such conflicts as "civil wars" could not have done so had they not moved outside of the conventional realist understanding of what "civil war" is. This understanding has more and more been unable, as is the case with IR in general, to account for what is happening on the ground. With time, circumstances or events on the ground arise that may come to affect (because of interpretation) the functioning or understanding of a concept. In this process, the perception of the existence or occurrence of the social phenomena that this concept identifies is also affected. With 
the inevitable passing of time, the possibility exists for the conceptual understanding (i.e. the "construction") of a social phenomenon that constitutes the social world to change with it. This explains how the perceived occurrence of "civil war" has varied among academic and political commentators because the function of the concept (i.e. the understanding or interpretation it exudes) has changed with time.

It is within this constructivist camp that this possibility for change with regard to the social dimensions of international relations is emphasised. ${ }^{43}$ This is based on the constructivist belief in "difference across context rather than a single objective reality" ${ }^{44}$ Rather than a single objective understanding of what "civil war" is, there can be different understandings expressed across contexts. So, while one understanding of the term "civil war" is applied in thinking about the American Civil War, for example, a different understanding is applied by those classifying the conflict in Iraq by the same term. Different understandings can therefore be expressed across contexts.

Constructivism, therefore, offers a theoretical explanation as to how "civil war" can be a migratory term. The challenge faced by realist theory, in bringing understanding to the political world, is founded upon this conceptual migration. It was in the debate over the conflict in Iraq following the American invasion of 2003, particularly the conflict that ran between the declared end to the invasion and the end of the US Administration of George W. Bush, that this challenge manifest itself as two opposing notions of "civil war" met. One of these notions was rooted in history and realist terms; the other was conceived in the constructivist mindset that says, "we occupy a world of our making”. 45

\section{The politics of language}

The Iraq debate was one that may be said to have begun when, on May 1 2003, George W. Bush, aboard the USS Abraham Lincoln, declared that major combat operations in Iraq had come to an end. ${ }^{46}$ His "speech and events surrounding it were widely publicised and served as the symbolic end to the war in Iraq". ${ }^{47}$ The question that arose subsequent to this announcement (made despite the continuation of conflict in that country) was this: in what terms were the events on the ground to be understood if not as a war between two states? For many, the conflict in Iraq was a "civil war". This classification was contested, however, and for two reasons. The first was founded upon political necessity and the second on the fact that the nature of the conflict in Iraq was contrary to a traditionally conceived notion of what civil war looks like. 
With regard to the first, "Governments embroiled in civil wars often do not want to label them as such" because in America's case specifically, it would give the impression of "chaos and disastrously failed policy". ${ }^{48}$ For the US Administration to have judged itself as involved in a civil war would have meant it no longer had a tight hold on the situation in Iraq and that it may well have managed to bog itself down in yet another 'Vietnam'. There would have been too much at stake for the Bush administration to "give up and go home" and so the best way of avoiding such a scenario would have been to argue that it did not exist.

It is the second reason, however, that was of greater interest to the purposes of the research being reported here. There were those who, aside from the political motive and despite having a character that was contrary to a traditionally conceived notion of civil war, perceived the conflict in Iraq as a "civil war". It was in the debate over whether the conflict in Iraq constituted a civil war or not that Stanford University professor, James Fearon, had the following to say:

Politics aside ...the definition of civil war is not arbitrary. For some - and perhaps especially Americans - the term brings to mind all-out historical conflicts along the lines of the U.S. or Spanish Civil Wars. According to this notion, there will not be civil war in Iraq until we see mass mobilisation of sectarian communities behind more or less conventional armies. ${ }^{49}$

Writing in the same year, however, and in the context of the same debate, Dan Smith - retired US army colonel and military affairs analyst - made the following claim: "[Mo]re than 65 percent of the U.S. public thinks Iraq is a civil war." ${ }^{50}$ In providing the grounds for debate, the existence of different notions of "civil war" preceded the need for political expedience on the part of the Bush Administration. The US government would not have had the need to argue against "civil war" classification of the conflict in Iraq had it not been for the existence of a notion of civil war different from the kind that "brings to mind all-out historical conflicts along the lines of the U.S. or Spanish Civil Wars" and which is applied to events on the ground in Iraq. ${ }^{51}$ The migration of the term "civil war" serves as the deeper theoretical reason - beyond political considerations - for why it is that the classification of the conflict in Iraq came to be contested. The arguments, opinions and statements that constituted the debate over the conflict in Iraq were indicative of this migration. 


\section{Opposing notions of "civil war"}

The debate over Iraq offered empirical evidence for the contention that our understanding of "civil war" has changed with time because it involved different notions, each applied to conflicts classified as "civil war" and separated by time. Fearon's commentary not only drew attention to the posterity of the American Civil War and the conceptual understanding of "civil war" that evokes thinking about this historical war, but also to how it was drawn in opposition to the nature of the conflict exhibited in Iraq, between the years 2003 and 2008. According to this notion of "civil war", the conflict in Iraq was not a civil war. It is to the conflict in Iraq and the arguments surrounding it that we will shortly turn. The objective will not be to make a judgement on classification. Rather, and for the sake of showing "civil war" to be a migratory term, it will be to show the incongruence between the nature of a conflict believed to be civil war and the conditions set out for civil war in the terms that classify a conflict as historical as the American Civil War.

John Keegan and Bartle Bull were two scholars who joined the Iraqi debate by arguing against civil war classification of the conflict. They asked whether Iraq could be, "the first civil war ever without battles, generals, explicit war aims, the use of partisan public rhetoric by civilian leaders, mass public participation and targets of a predominantly military nature?"52 Keegan went on to say that up until "the feuding groups are vying for national authority, have leaders who publicly announce what they are fighting for and clash in set-piece battles while wearing uniforms", what is happening in Iraq will remain separate from civil war. ${ }^{53}$ The value of their article - "What is a civil war"? - for this piece, is in its presentation of the conditions required for a conflict to be a civil war and that this notion included amongst others, the American Civil War in its category. ${ }^{54}$ It is the same notion, therefore, as that described by Fearon as bringing "to mind all-out historical conflicts along the lines of the U.S. or Spanish Civil Wars". ${ }^{55}$ In addition to this, and an important fact in understanding "civil war" as a contested term, it is a realist notion because it understands civil war as revolving around one of the core concepts of realism, namely sovereignty. In order for a conflict to be classified as civil war, Keegan and Bull argued that it needs to fulfil the "three principal defining aspects of a civil war": "The violence must be 'civil', it must be 'war', and its aims must be either the exercise or the acquisition of national authority." 56 


\section{Which state and whose people?}

What makes a war "civil" is that "the struggle must be conducted within a national territory, and that it must be carried on largely by the people of that territory, fighting between themselves. It must also involve a significant degree of popular participation". ${ }^{57}$ "National territory" is the territory of the state in question the state being that entity in IR that possesses "a permanent population, a defined territory and a government capable of maintaining effective control over its territory and of conducting international relations with other states". ${ }^{58}$ To say however, that a civil war only needs be conducted within a national territory would allow for no distinction between inter-state wars that can and have been fought in one national territory and intra-state wars, that can only be fought in one national territory. Consequently, that which is important for distinction is that the conflict must be engaged largely by the people of that territory. In other words, the war is known as "civil" because it pertains to or involves a conflict fought largely between the citizens of one state.

Up until February 2007, the "Coalition of the Willing” had, on its own (and excluding the US), involved the presence of nationals from as many as thirty-four different countries on Iraqi soil, while Fearon, writing in 2006, noted, “... neighbouring countries [such] as Iran and Syria are more covertly involved" ${ }^{59}$ According to US military and Iraqi sources, in 2006, Iraq had in it "several thousand Iranian agents of all kinds”. ${ }^{60}$ In his article describing Iran's role in Iraq, Doron Zimmermann claims that the violence "directed at the coalition forces and their Iraqi allies is a tool of Iranian statecraft in pursuit of checking perceived coalition and US regional ambitions" ${ }^{61}$ Iran is believed to have been nurturing local proxies of antiUS sentiment in Iraq, among which the Mahdi Army and the Badr Brigade, with Tehran also reported to have "invited its long-time client, the Lebanese Hizballah, into Iraq". ${ }^{62}$ It is with this foreign involvement in mind that Thomas Friedman argued, "Iraq is broken into so many pieces, 'divided among warlords, foreign terrorists, gangs, militias, parties, the police and the army’, that the conflict can't be said to constitute civil war." 63 The extent to which foreign or indigenous elements had a greater hand in the maintenance of violence following Bush's declaration aboard the USS Abraham Lincoln, remains contentious. This is so because of the absence of the militarised conflict discussed in the next section.

Aside from Keegan and Bull's five clear-cut cases of civil war in history all exhibiting popular participation, Keegan and Bull do not offer much else in elaborating on this pre-requisite for "civil war" classification. It is in explaining the 
requirement of "war" and its difference from lesser forms of violence that a better understanding of "popular participation" is gained.

\section{Violence that is war}

For a conflict to be classified as a "civil war" the violence must constitute "war" ${ }^{64}$ For Wright, war is (from the sociological point of view) "a socially recognised form of intergroup conflict involving violence". ${ }^{65}$ Keegan and Bull settle on "hostile [i.e. violent] contention by means of armed forces" that is military by nature. ${ }^{66}$ So how is it that "war" is different from forms of conflict that include coups d'états, communal conflict, terrorism and common crime? For Keegan and Bull, the existence of armed forces contending with one another in a hostile fashion will depend, apart from the fact that they are armed, on the violence in the conflict being of a military character. These military characteristics include battles, "uniforms, clear chains of command, acknowledged leadership, and official, public war aims". ${ }^{67}$ Their importance is also found in the fact that they purvey a "minimum degree of organisation, formality and identifiability of the combatants". ${ }^{68}$ So, rather than the battles having to be organised, their criteria require that the people are. ${ }^{69} \mathrm{By}$ this they mean that "war requires leaders who say what they are fighting for and why, and a public that understands what it is all about - the divisions ... and the goals." ${ }^{70}$ It is also only when the public have such an understanding that they can participate to a degree that may be described as "popular".

The civil violence in Iraq was "for the most part decidedly unmilitary". ${ }^{71}$ An important feature of the conflict that distinguished it from "war" in this regard was "the lack of public rhetoric against the enemy by popular leaders" ${ }^{72}$ "All of Iraq's leaders call constantly for unity, tolerance and an end to the violence." ${ }^{, 73}$ This was far from the case with the leaders in the civil wars cited by Keegan and Bull. ${ }^{74}$ The fact that there were "no, or almost no, battles in Iraq's domestic killing” contributed towards the perception that the conflict was "decidedly unmilitary". ${ }^{75}$ Keegan and Bull argued, in fact, that civilians were the principal targets. ${ }^{76}$ It is when civilians become the principal targets that the classification of "war" comes into question. The reason for this is quite clearly that civilians are distinguished by the fact that they fall outside of the armed forces. If those who fall outside of the armed forces come to be the principal targets of violence, that violence moves closer to being of a one-sided character and further away from being "hostile contention by means of armed forces". ${ }^{77}$ A conflict may exist, however, whereby state forces are not primary to it and civilians are killing one another - the violence is directed between factions or regions. In this situation, "The looser definition of the 'war' part of civil 
war ... acknowledges that if factions or regions are killing enough people for enough time, it can be petty not to recognise the conflict as something very like war."78 That which distinguishes such a conflict from "civil war", however, is the exclusion of state forces as primary to the violence. If the war is one over state control, it should be assumed that armed forces defending the state and those fighting against the state must be the principal targets of violence, rather than civilians. If this is not the case, the objective of the conflict and, in turn, its classification as a "civil war" in a conventional realist sense, comes into question. This is not to say that a civil war cannot incur any degree of civilian casualty. The point to be made is that if civilians are dying they cannot be the principal targets in the conflict if that conflict is to be classified as one in which acquisition of state authority is the primary objective.

\section{A struggle over what and between whom}

In 2006, the White House Press Secretary, Tony Snow, rejected the notion that a "civil war" was happening in Iraq based on the understanding that there were not yet "two clearly defined and opposing groups vying not only for power, but for territory" ${ }^{79}$ Officials of the Bush administration also argued that, because "there is no obvious political vision on the part of the Sunni-led insurgent groups ... 'civil war' does not apply" to Iraq. ${ }^{80}$ Essentially, the third defining aspect of a "civil war" for Keegan and Bull is authority. ${ }^{81}$ The aim of the violence must be "either the exercise or the acquisition of national authority" ${ }^{82}$ In other words, "The point of the violence must be sovereign rule: combatants must be trying either to seize national power or to maintain it." 83 IR theorists who describe "civil war" as "protracted internal violence aimed at securing control of the political and legal apparatus of a state" and who argue that "a conflict does not take on the characteristics of a civil war until an attempt is made to take over the basic functions of the state", confirm this third aspect. ${ }^{84}$ What does it mean however to take over the basic functions of the state? The basic functions of the state, as borne in the Westphalian ideal, revolve around "the provision of security, welfare and representation". 85

If "civil war" implies "the exercise or acquisition of national authority' or an attempt "to take over the basic functions of the state", it follows that authority or the basic functions of the state must be in place for the conflict to be classified as a "civil war". It is here that Freedman distinguished what he called a "classical civil war" from the situation that was likely in Iraq, in which the violence may not have lead to "civil war", "in which it is possible for one side to defeat the other in battle, but instead to a complete breakdown of social order so that there is no effective 
government at all”. ${ }^{86}$ What Freedman effectively argued then is that chronic intercommunal violence may result in one of two possible scenarios, the former constituting civil war and the latter, which he said was likely in Iraq, a failed state. In support of the latter, Fearon defined "civil war" as "involving attempts to grab power at the centre of government or in a given region" and argued that because there was a "vacuum of power" at the centre of Iraq, "communal violence will inevitably be tied to struggles for political power and control", rather than a struggle for state control. ${ }^{87}$ According to this view, there was no state control to be fought over, so it was not a civil war.

During his visit to Iraq in November 2006, George W. Bush handed Nuri Kamal al-Maliki (Iraqi Prime Minister) "a memorandum advising him that, without additional American resources, the Iraqi leader would almost certainly be unable to turn back the tide of sectarian violence". ${ }^{88}$ Byman and Pollack only referred to the US and its allies in prescribing possible solutions to the complications caused by the foreign intervention of Iran and made no mention of the role to be played by the Iraqi government itself. ${ }^{89}$ Packer added to this sentiment of ineffectiveness on the part of the Iraqi government and a sense of complete breakdown of social order when describing how “[t]he CPA's [Coalition Provisional Authority] failure to disarm the militia ... left almost every city in Iraq under the real control of an ethnic group rather than the government."90

In direct opposition to this line of thinking, however, Matt Lauer argued that Iraq was in a "civil war", despite recognising the absence of an effective government that was able to protect the people. ${ }^{91}$ His argument was based on the fact that "two Muslim groups, the Sunnis and the Shiites, are using violence against each other". ${ }^{92}$ Similarly, Sam Gardiner, a retired US air force colonel argued, "Iraq is a failed state ... and cannot provide security, so the fact that the government remains in place is irrelevant to the debate about whether the conflict is a civil war." 93 Gardiner's understanding of "civil war" does not consider the existence of a government, let alone an authoritative or effective one.

Wong stated, "one of the sides in a civil war is almost always the sovereign government". ${ }^{94}$ It is with this condition in mind that some scholars argued that the civil war in Iraq began "when the Americans transferred sovereignty to an appointed Iraqi government in June 2004". 95 This was believed to have "officially transformed the anti-American war into one of insurgent groups seeking to regain power for disenfranchised Sunni Arabs against an Iraqi government led by Ayad Allawi [interim Prime Minister of Iraq prior to the country’s 2005 legislative elections] and 
increasingly dominated by Shiites". 96 This line of thinking raises the question, however, as to whether the Iraqi government, seemingly ineffective in providing a basic level of security to its people, and still very much aided by US and coalition troops, was sovereign during the time of the conflict in question.

In the southern half of Iraq, the US invasion and subsequent ousting of the Hussein regime gave rise to a malaise of residential claims and counter-claims between Arabs and Kurds. After being displaced by returning Kurds, an Arab man remarked, "Where is the government that will give us our rights? Is it from America? From the Iraqi government? We don’t know."97 A Kurdish man repeated this sentiment when he said, "I really don't know who will give us a house, because there are many governments in Iraq." An Arab man claimed, "Only god and America can solve the problem." the new Iraqi government, a Kurdish women interrupted by asking, "Is there a government right now or not? I know nothing." "99 The question as to who constituted the Iraqi government and its degree of effectiveness casts doubt not only upon the existence of sovereign rule as a pre-requisite for civil war in realist terms, but also the degree to which the conflict was one in which the people understood "what it is all about - the divisions ... and the goals”. ${ }^{100}$

Frederick Robertson, a 19th-century English preacher, said, "Men will ever distinguish war from mere bloodshed." ${ }^{101}$ The debate over Iraq suggested this distinction is as challenged as the conventional realist concept of civil war. This is so because there were those who, having been guided by the death toll and levels of violence alone, came to see Iraq as a "civil war". With many scholars claiming that "the bloodshed in Iraq ... puts the country in the top ranks of nations stricken by civil wars in the last half-century", others were more specific, arguing that "the deaths per year in Iraq ... place this conflict among the worst 20 civil wars of the past 60 years". ${ }^{102}$ Nicholas Sambanis, a political scientist at Yale University, made the most significant observation when he argued, "The level of violence is so extreme that it far surpasses most civil wars since 1945."103 It is due to perceptions like these that many have been left dumbfounded as to how Iraq can be denied classification as a civil war.

Those who, in 2006, had described Iraq as a "civil war" based on the level of violence exhibited between two sectarian groups, argued that "civil war" began earlier in that year, "after the bombing of a revered Shiite shrine in Samarra set off a chain of revenge killings that left hundreds dead over five days and has yet to end". ${ }^{104}$ A month after the bombing, the Iraqi Prime Minister, Nuri Kamal al-Maliki, 
was recorded as having said, "If this is not civil war, then God knows what civil war is." Similarly, and despite having argued on an earlier occasion that Iraq was not a civil war because of the vacuum of power, Fearon argued, "the level of violence in Iraq meets the definition of civil war that any reasonable person would have" ${ }^{105}$ To which degree, however, was the bombing of the shrine and the violence that ensued, an act of insurgency against the government and to which degree was the government involved in the reprisal that followed the act? Here it may be necessary to note the definition of "insurgency" offered by Evans and Newnham who describe it as "an armed insurrection or rebellion against an established system of government in a state" ${ }^{106}$ They continue, "If the violent challenge by the insurgents is forcefully resisted by the incumbents, and it normally is, a civil or internal war situation will result.",107

In short, how close is the definition of civil war "that any reasonable person would have", to the conventional realist definition - one that requires more than just a certain level of internal violence? Based on the argument by Fearon, and bearing in mind the conditions for civil war set out in the conventional realist criteria, the two are not close at all. Baghdad correspondent for CNN (Cable News Network), Michael Ware, argues, "You drive in a minibus on your way to work. Suddenly, there's a checkpoint. If you're of the wrong faith, you are dead ... If that's not civil war ... then honestly I don't know what is." ${ }^{108}$ Ware's description does not come close to the conventional realist conditions set out for civil war. The only recognition his depiction of events on the ground would receive from any realist thinker who has a view on civil war would be that of sectarian violence.

In addition to and closely related to the levels of violence and questions over the effectiveness of the Iraqi government, there were "several different conflicts going on in Iraq", with many communities divided, "fighting against one another more than against their supposed enemies". ${ }^{109}$ Adding to the malaise of fighting was the number of local and foreign "armed forces" already noted - divided by their different objectives. These observations testify to an element of the conflict in Iraq that contributes significantly towards the multifarious nature of its dynamics and Freedman's sense of a conflict very different from what he calls the "classical civil war". The fact that several different conflicts were going on in Iraq during the time under consideration was an obvious consequence of the fact that "not all insurgents in Iraq are the same, share the same ideology or fight for the same end goals". ${ }^{110}$ Magnus Norell described what he believed to be an "insurgency" in Iraq, as having its origin in two sources or groups. ${ }^{111}$ The largest of these consisted of native Sunni Islamists or former members of the now non-existent Ba'ath Party. ${ }^{112}$ Having once 
dominated Iraqi politics, its actions against the government were motivated by the fear that its members would become second-class citizens in a predominantly Shi'a dispensation. ${ }^{113}$ The second group consisted of foreign jihadis - recruited by various radical networks in the Middle East and in Europe. ${ }^{114}$ Unlike the native Sunni insurgents, the jihadis primarily had a religious agenda. Removing the new government and sparking a civil war between the Sunni's and Shi'a - thereby making it increasingly difficult for the American and coalition operations in Iraq was only part of the larger Jihad againt the West and the desire to remove the state enterprise antithetical to Islamic beliefs. ${ }^{115}$ It is also important to note that the "insurgents" were not only pitted against the government of Iraq, whoever it was and however legitimate it may have been, but also against one another. The Jihad objective of destroying Iraq as a state was in direct contention with that of the indigenous Sunnis who wanted not a failed state, but a different state. ${ }^{116}$ It is with this in mind that some scholars argued,

... the civil war in Iraq has elements of both an insurgency - one side is struggling to topple what it sees as an illegitimate national government - and a sectarian war - the besieged government is ruled by Shiites and opposed by Sunni Arabs. ${ }^{117}$

\section{Conclusion}

The fact that "conceptual thinking about civil war, at least among political scientists post-1945, has been conspicuous either by its absence or limited presence on the margins of debates about global politics" is in large part due to the traditionally dominant position of political realism. ${ }^{118}$ This dominance has meant an emphatic concern with what happens between states, rather than what happens inside of them, when describing world affairs. ${ }^{119}$ It is conceivable then that as much as realism has dominated the theory of world politics, so too civil war has largely found itself outside the political thinking of IR theorists. The fact that the Cold War was dubbed the "Long Peace" despite the high incidence of internal conflict and its resultant deaths of six and a quarter million people is indicative of this. ${ }^{120}$ However, America's invasion of and continued involvement in Iraq, together with the ensuing debate over the nature of the conflict that followed Bush's declaration of an end in major combat operations, did a great deal to add credence to discussion over civil war in the arena of political and academic thought.

Despite the conflict in Iraq not having met the prescribed conditions for civil war inherent in the conventional realist definition, there were many who claimed it was a civil war. This truth confirms the migration of "civil war" as a term from its 
conventional realist understanding to a concept of "civil war" that is dependent on a collective agreement that will vary across contexts. Those who argued in favour of "civil war" classification of the conflict in Iraq based their views largely on the levels of violence, the death toll, and the fact that this all happened in the midst of two Muslim groups who were fighting one another within a single state. ${ }^{121}$ It is not necessarily the case, however, that a "new" definition of "civil war" exists. The concept of "civil war", conceived outside of the realist paradigm and within the constructivist mindset, does not articulate clearly defined criteria to the extent found in the realist definition. Where once the classification of a conflict as "civil war" would have been based on clearly articulated and definitive realist criteria, the term now seems to have become more open-ended and less restrictive in its classification to the degree that "Quite often what constitutes civil war is in the eye of the beholder."122

For Van der Westhuizen, the concepts we use are products of the times within which we use them - a sentiment shared by constructivist theory. ${ }^{123}$ The realist notion of "civil war" is indicative of a time when the predominance of the state as a unit of analysis in IR theory was founded upon the certainty of the state in stemming external influences and maintaining a greater degree of sovereignty. The concept of "civil war" conceived in the constructivist mindset on the other hand, is indicative of the turbulence that Rosenau describes as characteristic of contemporary world politics. Here it can be seen how "Periods of transformation tend to undermine conceptual clarity."124 This turbulence questions the validity and utility of traditional structures and concepts in understanding the contemporary world in which we live and encourages the migration of terms.

Reflecting on the consequences of the migration of "civil war" is an endeavour best left to a later study. Here, research on how a shift in the understanding of "civil war" is likely to affect civil war discourse and the associated implications for political analysis, may render useful findings. There are those, for example, who - for the sake of vigilance in the social sciences - ensure that useful concepts do not become devalued through overextension and who would show opposition to the idea that "civil war" is a shifting concept. The implications of how we understand "civil war" and how we apply these understandings in our world also go beyond those of just an academic nature. There are also social and political implications. Here, an outstanding and contemporary example exists in the debate over Iraq. 
Social constructivism provides us with the theoretical explanation underlying migration, not only for "civil war" but also potentially for any object or concept of our knowledge. It is because "civil war" is a migratory term that Iraq was more than a site of physical conflict, but also an event on the ground that encompassed a contest around classification. The debate surrounding the conflict in Iraq in light of constructivist theory allows sense to be made of the concurrent claims that civil wars have increased in occurrence while also changing in their nature. As unfortunate as the conflict may have been, it was timely in bringing attention firstly to how civil war is understood at the end of a century that is argued to have seen a rapid increase in civil wars together with a change in the nature of these conflicts, and secondly, to what it means when we say that civil war has changed.

\section{Endnotes}

${ }^{1}$ This article is based on a thesis submitted in December 2009 to Rhodes University, Grahamstown, in partial fulfilment of the requirements for the degree of Master of Arts in International Studies.

${ }^{2}$ Kennedy-Pipe, C \& Jones, C. “An introduction to civil wars”. Civil Wars 1/1. 1998. 3.

${ }^{3}$ Ibid.

${ }^{4}$ Duyvesteyn, I. “Contemporary war: Ethnic conflict, resource conflict or something else?” Civil Wars 3/1. 2000. 93.

${ }^{5}$ Smith, D. "A rising tide of blood: The semantics of civil war". Counter Punch. December 2006. <http://www.counterpunch.org/smith12022006.html> Accessed on 25 January 2008.

${ }^{6}$ Kalyvas, SN. “'New' and 'old’ civil wars: A valid distinction?” World Politics 54/1. 2001. 99-118; Berdal, M. “How 'new' are 'new wars'? Global economic change and the study of civil war”. Global Governance 9/4. 2003. 477-502; Wong, E. "Scholars agree Iraq meets definition of 'civil war'”. International Herald Tribune. 26 November 2006.

$<$ http://www.iht.com/bin/print.php?iddd=3675083> Accessed on 17 December 2007.

${ }^{7}$ Fierke, KM. “Constructivism”. In: Dunne, T, et al. (eds), International relations theories: Discipline and diversity, Oxford: Oxford University Press, 2007, 183; The author disputes the idea that constructivism offers a holistic explanation as to how the social world in which we live was and continues to be created. What matters beyond this point (and as far as the purposes of this article are concerned) is that constructivism does offer an explanation as to how and why 'civil war' is a migratory term.

${ }^{8}$ Adler, E. “Constructivism and international relations”. In: Carlsnaes, W, et al. (eds), Handbook of international relations, London: Sage, 2002, 95. 
${ }^{9}$ Fierke op. cit., p. 183.

${ }^{10}$ Adler op. cit., p. 100.

${ }^{11}$ Fierke op. cit., p. 171.

${ }^{12}$ Jackson, R \& Sørensen, G. Introduction to international relations: Theories and approaches, $3^{\text {rd }}$ edition. Oxford: Oxford University Press, 2007, 164.

${ }^{13}$ Ibid., p. 165.

${ }^{14}$ Adler op. cit., p. 95.

${ }^{15}$ Van der Westhuizen, J. (ed), Ideas, cultural forces and the development of international relation. Halifax: Centre for Foreign Policy Studies, 1997, 43.

${ }^{16}$ Fierke op. cit., p. 174.

${ }^{17}$ Ibid., p. 175.

${ }^{18}$ Reus-Smit, C. “Constructivism”. In: Burchill, S, et al. (eds), Theories of international relations, New York: Palgrave, 2001, 218.

${ }^{19}$ Jackson \& Sørensen op. cit., p. 164; Fierke op. cit., p. 171.

${ }^{20}$ Jackson \& Sørensen op. cit., p. 162.

${ }^{21}$ Van der Westhuizen op. cit., p. 43.

${ }^{22}$ Swannell, J. (ed), The Oxford Modern English Dictionary. Oxford: Clarendon Press, 1992, 214.

${ }^{23}$ Miller, D. Disciplining nations: The power of truth to transform cultures. Seattle: YWAM, 1998, 125.

${ }^{24}$ Fierke op. cit., pp. 171, 175.

${ }^{25}$ Van der Westhuizen op. cit., p. iii.

${ }^{26}$ Ibid., p. 22.

${ }^{27}$ Ibid.

${ }^{28}$ Burchill, S. "Realism and neo-realism”. In: Burchill, S \& Linklater, A (eds), Theories of international relations, New York: St. Martin's Press, 1996, 68. ${ }^{29}$ Ibid., p. 80.

${ }^{30}$ Ibid., pp. 88-89.

${ }^{31}$ Van der Westhuizen op. cit., p. 2.

${ }^{32}$ Berdal op. cit., p. 488.

${ }^{33} \mathrm{Ibid}$.

${ }^{34}$ Mathews, JT. "Power shift”. Foreign Affairs 76/1. 1997. 50.

${ }^{35}$ Ibid., p. 61.

${ }^{36}$ Rosenau, JN. Turbulence in world politics: A theory of change and continuity. New York: Harvester Wheatsheaf, 1990, back cover.

${ }^{37}$ Ibid., p. 8.

${ }^{38}$ Ibid., p. 9.

${ }^{39}$ Ibid., p. 4.

${ }^{40}$ Ibid., pp. 5-6.

${ }^{41}$ Baev, P. "International dimensions of civil war". Centre for the Study of Civil War. 2003-2005. <http://www.prio.no/CSCW/Research-andPublications/Past-working-groups/International-Dimentions-of-Civil-WarWG1-2003-2005/> Accessed on 7 August 2011. 
${ }^{42}$ Ibid.

${ }^{43}$ Fierke op. cit., p. 167.

${ }^{44}$ Ibid., p. 168.

${ }^{45}$ Ibid., p. 183

${ }^{46}$ Bash, D. "White House pressed on 'mission accomplished' sign”. CNN.com. 29 October 2003.

<http://www.cnn.com/2003/ALLPOLITICS/10/28/mission.accomplished/>

${ }^{47}$ Ibid. Accessed on 5 October 2009

${ }^{48}$ Wong op. cit.; Brenjo, N. “Iraq and civil war: What's in a label?” Reuters Alertnet. 30 November 2006.

<www.alertnet.org/printable.htm?URL=/db/blogs/1265/2006/10/30-1631001.htm> Accessed on 17 December 2007.

${ }^{49}$ Fearon, JD. “civ/il war (siv-el wor), n. 1 a violent conflict between organized groups within a country”. Washington Post. 9 April 2006.

$<$ http://cddrl.stanford.edu/news/civil_war_definition_transcends_politics_20 060410/> Accessed on 6 August 2008.

${ }^{50}$ Smith op. cit.

${ }^{51}$ Fearon op. cit.

${ }^{52}$ Keegan, J \& Bull, B. “What is a civil war?” Prospect 129. December 2006. 20.

${ }^{53}$ Wong op. cit.

${ }^{54}$ Keegan \& Bull op. cit., p. 18.

${ }^{55}$ Fearon op. cit.

${ }^{56}$ Keegan \& Bull op. cit., p. 18.

${ }^{57}$ Ibid.

${ }^{58}$ Evans, G \& Newnham, J. The Penguin Dictionary of International Relations. London: Penguin Books, 1998, 512.

${ }^{59}$ GlobalSecurity.org. "Iraq coalition troops: Non-US forces in Iraq”. GlobalSecurity.org. February 2007.

<http://www.globalsecurity.org/military/ops/iraq_orbat_coalition.htm> Accessed on 12 August 2008; Fearon op. cit.

${ }^{60}$ Byman, DL \& Pollack, KM. “What next?”. washingtonpost.com. 20 August 2006. $<\mathrm{http}: / /$ www.washingtonpost.com/wpdyn/content/article/2006/08/18/AR20060818009> Accessed on 17 December 2007.

${ }^{61}$ Zimmermann, D. “Calibrating disorder: Iran's role in Iraq and the coalition response, 2003-2006”. Civil Wars 9/1. 2007. 8.

${ }^{62}$ Ibid., p. 13.

${ }^{63}$ Brenjo op. cit.

${ }^{64}$ Keegan \& Bull op. cit., p. 18

${ }^{65}$ Wright, Q. A study of war, $2^{\text {nd }}$ edition. Chicago, IL: University of Chicago Press, 1964, 6.

${ }^{66}$ Keegan \& Bull op. cit., p. 18. 
${ }^{67}$ Ibid., p. 19.

${ }^{68}$ Ibid., p. 1.

${ }^{69}$ Ibid., p. 18.

${ }^{70}$ Ibid.

${ }^{71}$ Ibid., p. 19.

${ }^{72}$ Ibid., p. 20.

${ }^{73}$ Ibid.

${ }^{74}$ Ibid.

${ }^{75}$ Ibid.

${ }^{76}$ Ibid.

${ }^{77}$ Ibid., p. 18.

${ }^{78}$ Ibid., p. 20

${ }^{79}$ Smith op. cit.

${ }^{80}$ Wong op. cit.

${ }^{81}$ Keegan \& Bull op. cit., p. 18.

${ }^{82}$ Ibid.

${ }^{83}$ Ibid.

${ }^{84}$ Evans \& Newnham op. cit., p. 64; Kennedy-Pipe \& Jones op. cit., p. 1.

${ }^{85}$ Williams, PD. "State failure in Africa: Causes, consequences and responses”. In: Africa South of the Sahara 2009, $38^{\text {th }}$ edition, London: Routledge: Europe Regional Surveys of the World, 2008, 21.

${ }^{86}$ Freedman, L. "What makes a civil war?” BBC News. 20 April 2006. <http://news.bbc.co.uk/go/pr/fr/-/1/hi/world/middle_east/4902708.stm> Accessed on 1 May 2007.

${ }^{87}$ Fearon op. cit.

${ }^{88}$ Guardian Editorial. "Language and war: Conflicted meanings”. The Guardian. 30 November 2006.

<http://www.guardian.co.uk/commentisfree/2006/nov/30/iraq.comment> Accessed on 4 August 2008.

${ }^{89}$ Byman \& Pollack op. cit.

${ }^{90}$ Packer, G. The Assassins' Gate: America in Iraq. London: Faber \& Faber, 2006, 336. [check title - the assassins'?]

${ }^{91}$ Janensch, P., "Words have meaning in Iraq war”. CONNPOST.com. 19 February 2007. <http://www.connpost.com/pauljanensch/ci_4764620?source=email> 92 Ibid. Accessed on 17 December 2007.

${ }^{93}$ Brenjo op. cit.

${ }^{94}$ Wong op. cit.

${ }^{95}$ Ibid.

${ }^{96}$ Ibid.

${ }^{97}$ Packer op. cit., p. 352.

${ }^{98}$ Ibid., p. 361.

${ }^{99}$ Ibid. 
${ }^{100}$ Keegan \& Bull op. cit., p. 18.

${ }^{101}$ Smith op. cit.

${ }^{102}$ Wong op. cit.

${ }^{103}$ Ibid.

${ }^{104}$ Ibid.

${ }^{105}$ Ibid.

${ }^{106}$ Evans \& Newnham op. cit., p. 252.

${ }^{107}$ Ibid.

${ }^{108}$ Brenjo op. cit.

${ }^{109}$ CBC News in depth: Iraq. “Q\&A: Conflict expert Roland Paris on whether Iraq is in a civil war”. CBC News. 6 December 2006.

$<$ http://www.cbc.ca/news/background/iraq/paris-qa.html> Accessed on 17

December 2007; Byman \& Pollack op. cit.

${ }^{110}$ Norell, M. “Iraq - quo vadis?” Civil Wars 9/1. 2007. 5.

${ }^{111}$ Ibid., p. 3

${ }^{112}$ Ibid.

${ }^{113}$ Ibid., p. 4

${ }^{114}$ Ibid., p. 3.

${ }^{115}$ Ibid., p. 4

${ }^{116}$ Ibid.

${ }^{117}$ Wong op. cit.

${ }^{118}$ Kennedy-Pipe \& Jones op. cit., p. 3.

${ }^{119}$ Ibid.

${ }^{120}$ Ibid.

${ }^{121}$ Fearon op. cit.

${ }^{122}$ Kennedy-Pipe \& Jones, op. cit., p. 1.

${ }^{123}$ Van der Westhuizen op. cit., p. iii.

${ }^{124}$ Rosenau op. cit., p. 34. 